Relations industrielles

Industrial Relations

\title{
Deferment Policy in the Selective, by David R. Bradford, Princeton, N.J., Industrial Relations Section : Princeton University, 1969, 64 pages.
}

\section{Joan Sichel}

Volume 25, numéro 1, 1970

URI : https://id.erudit.org/iderudit/028111ar

DOI : https://doi.org/10.7202/028111ar

Aller au sommaire du numéro

Éditeur(s)

Département des relations industrielles de l'Université Laval

ISSN

0034-379X (imprimé)

1703-8138 (numérique)

Découvrir la revue

Citer ce compte rendu

Sichel, J. (1970). Compte rendu de [Deferment Policy in the Selective, by David R. Bradford, Princeton, N.J., Industrial Relations Section : Princeton University, 1969, 64 pages.] Relations industrielles / Industrial Relations, 25(1), 154-155. https://doi.org/10.7202/028111ar

Tous droits réservés (C) Département des relations industrielles de l'Université Laval, 1970
Ce document est protégé par la loi sur le droit d'auteur. L'utilisation des services d'Érudit (y compris la reproduction) est assujettie à sa politique d'utilisation que vous pouvez consulter en ligne.

https://apropos.erudit.org/fr/usagers/politique-dutilisation/ 
L'auteur, dans sa deuxième partie, discute de la nécessité d'un certain contrôle judiciaire en certaines matières relevant des relations du travail. Se basant sur la constitution canadienne, sur les principes du droit écrit et de la justice naturelle, il rejette l'idée de soustraire d'une façon absolue le tribunal administratif au pouvoir de surveillance du tribunal de droit commun pour favoriser plutôt une intervention judiciaire dans des limites restreintes qui peuvent être différentes selon les secteurs du droit administratif.

Dans la troisième partie, on suit avec intérêt l'évolution de l'intervention étatique en matière de relations du travail jusqu'à la négociation collective obligatoire. L'auteur fait ressortir le rôle des tribunaux qui n'a pas toujours été négatif et qui est complémentaire dans la mise à exécution de la convention collective.

Confrontant, ensuite, la Commission des relations de travail, arbitres et conciliateurs avec une véritable indépendance dans l'exercice de leurs fonctions, il fait ressortir certaines faiblesses (les pressions dont ils sont l'objet et interventions gouvernementales et ministérielles) qui contribuent à gêner leur autonomie.

Enfin, l'auteur souligne l'élément important qu'est le facteur temps dans les matières relevant du Code du travail. A cause des besoins particuliers à la négociation collective, des moyens doivent $\hat{\mathrm{e}}$ tre trouvés pour éliminer les longs délais provoqués par la revision judiciaire des matières relevant du Code du travail. Il souligne, d'une part, les principales faiblesses de l'appareil judiciaire actuel qui est encore à la recherche d'une véritable doctrine d'un système de négociation collective auquel on reconnaît une certaine autorité sans qu'il soit besoin de reprendre constamment la discussion sur l'effet de la clause privative en matière de relations du travail. Il suggère en outre une simplification de la procédure qui remplacerait les brefs de prohibition, certiorari et mandamus par une procédure sommaire unique au même effet. Ses recommandations ont le mérite de respecter l'esprit de notre tradition judiciaire et par là d'être plus facilement acceptables et réalisables.

On doit souligner le grand souci de clarté de l'ouvrage du docteur Cutler dans son exposé et dans la présentation. Il est une contribution importante au droit du travail et un instrument de base qui sera très utile autant pour les avocats, les étudiants que pour tous ceux qui s'intéressent aux relations de travail.

Nicole L'HEUREUX

Deferment Policy in the Selective, by David R. Bradford, Princeton, N.J., Industrial Relations Section: Princeton University, 1969, 64 pages.

This brief study describes the American Selective Service policies, and focuses on the changes made to the Universal Military Training and Service Act (1951) which formed the framework of the present Military Selective Service Act (1967), specifically in regard to deferment policy and the changing needs for military manpower.

This paper undertakes an examination of the problems posed in the period $1960-67$, an analysis of the changes made in 1967, and an examination of an alternate system that tries to redress the defects. This work is an outgrowth of an earlier one the author, an economist, prepared as a consultant to the National Advisory Commission on Selective Service in 1966-67.

In the 1960's, a reassessment of the Selective Service System was prompted by a widespread dissatisfaction with its performance in terms of equity and certainty. The charge of inequity arose primarily from the relatively low rates of participation by men at the two extremes of the educational (and correspondingly economic) spectrum of society. The changes made in 1967 appear to limit or even eliminate the advaritageous treatment of the highly educated. However, the problem of draft uncertainly still remains.

The objectives of a selective service system should include 1) flexibility, 2) economy, 3) equity, 4) certainty, and particularly considered by the author, 5) public acceptance. Changing demands for military manpower have led to changes in deferments. Three of the most important deferments specifically authorized before the changes in 1967 were the deferment of 1) fathers, 2) students, and 3 ) on grounds of occupation. It was the student deferment that led to controversy, mostly on the grounds of inequity. 
The changes in the law have led to fewer, more restricted deferments. Undergraduate deferments were no longer discretionary. Deferments could no longer be compounded. Anyone deferred as a student, for example, was disqualified from deferment on grounds of fatherhood except in cases of extreme hardship. Graduate student deferments were restricted to those studying medicine or narrowly related subjects. As well, with these changes the problems of high induction age and longer draft uncertainty have been exacerbated.

The author concludes with suggestions to deal with the potential problem of the rising involuntary induction age. $\mathrm{He}$ also discusses alternative mechanisms for determining sequence of induction of 1-A registrants (by age group and by a lottery system) which implies relinquishing the oldest-first rule.

The selection procedures for the armed forces relate directly to both the efficiency of the armed forces and the use and allocation of manpower in the civilian economy. For this reason, this detailed paper merits the consideration of those involved in manpower plans.

\section{Joan SICHEL}

\section{L'entreprise moderne et le management,} par Pierre Schil, Paris, Entreprise moderne d'édition, 1969, 132pp.

Un livre qui se veut avant tout pratique et qui s'adresse aux chefs d'entreprises moyennes. L'optique est définie d'emblée dans l'avant propos: l'entreprise moyenne - 200 ouvriers ou moins s'adaptera ou disparaîtra. Cette évolution doit répondre à deux séries d'objectifs d'ailleurs complémentaires, soit "d'une part, un accroissement de productivité de rendement, en même temps qu'un accroissement de production (et) d'autre part, une promotion sociale qui attribue à chacun, à tous les échelons, une part importante des fruits du travail et de ses responsabilités" (p. 127). Il n'y a pas d'autre alternative possible et rationnelle.

Bien que conçu en fonction d'un contexte qui n'est pas le nôtre, en 1963 l'on comptait en France que 35 établissements comprenant plus de 5,000 salariés (p. 18). Cet ouvrage qui se veut simple et qui l'est, devrait intéresser plus d'un patron québécois par sa clarté et les réflexions pertinentes de l'auteur concernant les fonctions du chef d'une entreprise moyenne quelles soient d'ordre économique, organisationnel ou social.

Pour le scientifique et plus particulièrement pour le sociologue intéressé aux relations industrielles, la lecture de cet ouvrage est réconfortante à un autre titre puisqu'il constitue l'indice possible d'un renouvellement substantiel et prometteur du comportement et des préoccupations du chef d'entreprise moyenne que l'on souhaiterait largement partagé par ses pairs dans la mesure où il rompt avec le conformisme intransigeant d'un milieu social plus soucieux de survivre à n'importe quel prix que de travailler à l'expansion économique de l'ensemble et de maintenir un système de relations de travail périmé parce que marqué du sceau du paternalisme quand il ne tend pas à l'assujetissement des salariés.

\section{Bernard SOLASSE}

The Exceptional Executive, a Psychological Conception, by Harry Levinson, Cambridge, Mass., Harvard Business Press, second printing, 1969, 297 pp.

Cet ouvrage s'adresse d'abord aux administrateurs. L'auteur a voulu mettre à leur disposition une synthèse des contributions de la théorie, de la recherche et de l'expérience qui leur permette de mieux comprendre les exigences du leadership et les effets de son exercice sur les hommes, l'organisation et le milieu.

En appliquant la théorie psychanalytique aux notions de leadership, de travail et d'organisation, l'auteur leur donne une signification nouvelle, ou du moins originale, et qui a le mérite de permettre de mieux situer les contributions des autres théories psychologiques et administratives qui y vont chacune de leur point de vue sur ces sujets. Face à l'analyse de Levinson, un bon nombre de clichés, de slogans et d'idées toutes faites s'estompent. Pour l'auteur, il n'existe pas de solutions pré-déterminées aux problèmes humains de l'organisation et seule la compétence d'administrateurs connaissant bien les mécanismes humains et la nature de l'organisation, permettra de trouver des solutions qui ont bien des chances d'être différentes dans chaque cas. Levinson, 